Verheij, R.A., Bakker, D.H. de, Groenewegen, P.P. Is there a geography of alternative medical treatment in The Netherlands? Health \& Place: 1999, 5(1), 83-97

\begin{tabular}{|c|c|}
\hline $\begin{array}{l}\text { Postprint } \\
\text { Version }\end{array}$ & 1.0 \\
\hline Journal website & http://dx.doi.org/10.1016/S1353-8292(98)00043-4 \\
\hline Pubmed link & http://www.ncbi.nlm.nih.gov/pubmed/10670993 \\
\hline DOI & $10.1016 / \mathrm{S} 1353-8292(98) 00043-4$ \\
\hline
\end{tabular}

This is a NIVEL certified Post Print, more info at http://www.nivel.eu

\title{
Is there a geography of alternative medical treatment in The Netherlands?
}

\author{
Robert A. VERHEIJ , DinNy H. DE BAKKER, PETER P. GROENEWEGEN \\ Netherlands Institute of Primary Health Care (NIVEL), P.O. box 1568, 3500 BN Utrecht, \\ Netherland
}

\begin{abstract}
An increasing number of people are using alternative medical care. The literature suggests that there are important between place variations, however. This paper tries to assess the extent of these variations and mechanisms behind them for the utilization of homeopathy, paranormal healing and manual therapy. Are these variations a matter of level of supply, degree of urbanization, GP characteristics or simply a matter of composition of populations? Data are derived from the Dutch National Survey of General Practice and analyzed using multilevel logistic regression models. Between place variation in utilization of homeopathy is mainly a matter of composition of populations with respect to health locus of control and religion. With respect to paranormal healing, it is exclusively a matter of religion. With respect to manual therapy, place variations are a matter of individual, GP, as well as area characteristics, but a relatively large amount remains unexplained.
\end{abstract}

\section{INTRODUCTION}

An increasing number of patients worldwide use alternative medical care. In France more than $30 \%$ of the population uses alternative medicine, in Great Britain 10\% (GoldbeckWood et al., 1996). About $20 \%$ of Australians visited some alternative practitioner in the past year (MacLennan et al., 1996). In the Netherlands between 1985 and 1990, the percentage of users of alternative medicine (not a GP) grew from 4.5 to $5.9 \%$ (Verweij, 1992). Also among general practitioners there seem to be few objections against alternative medicine. About 50\% occasionally practices alternative medicine (Visser and Peters, 1990) and many Dutch GPs believe in the efficacy of common alternative procedures (Knipschild et al., 1990). Health insurers as well feel that there is a great demand for alternative medicine. Some of the most popular forms of alternative medicine, like homeopathy, acupuncture and manual therapy are included in most insurance policies. According to some this is a very undesirable development (Van der Smagt, 1988). Alternative medicine is associated with irrationality and quackery and it is considered to be a danger for public health. Research on the other hand shows that patient satisfaction is high among users of alternative medicine (Fleuren et al., 1990; Visser and Peters, 1994), although the efficacy of treatment is questionable (Fleuren et al., 1990; Kleijnen et al., 1993). This means that there is clearly a 'market' for alternative medi- cine. This is also the viewpoint of the 
Verheij, R.A., Bakker, D.H. de, Groenewegen, P.P. Is there a geography of alternative medical treatment in The Netherlands? Health \& Place: 1999, 5(1), 83-97

Dutch government, which does not object to alternative medicine, although the use of reallynive dama- ging therapies needs to be discouraged and quality promoted (Ministry of Health, 1996).

Since the 1980's, much research was carried out to get a clearer picture of the utilization of alternative medicine. Comparisons of users and nonusers have shown that users are more often women, higher educated, less healthy, in the middle age groups with a higher prevalence of psychosocial problems and a different attitude towards health care (Limberger et al., 1981; Fulder and Munro, 1985; Visser, 1988; Furnham and Smith, 1988; Fleuren et al., 1990; Spigelblatt et al., 1994; Visser and Peters, 1994; Van Wijk et al., 1995; MacLennan et al., 1996; Goldbeck-Wood et al., 1996). Also religion seems to be related to alternative medicine: utilization among protestants is higher (Limberger et al., 1981). Very little research has been carried out on the geography of alternative medical care utilization, however. Research that does exist indicates that utilization does vary between regions. In the USA it was found that there is an effect of place of residence in the utilization of chiropractors, (Shekelle et al., 1995). In the Netherlands it was found that alternative medical treatment varies greatly between public health regions, controlling for subjective health status, socio-economic variables and lifestyle (Van Wijk et al., 1995). Findings from the CBS-Health Interview Survey (Frenken, 1990) indicate higher percentages of users in some provinces (Fig. 1). The question of what causes such variations has not been answered yet. First of all, there may be effects of the composition of populations. Areas counting a higher percentage of higher educated individuals would for example have higher utilization figures. A second possibility is that geographic variations in utilization are associated with variations in supply. Assuming that the probability of utilization increases when access costs are smaller, we may expect decreasing utilization with increasing distance. Third, there may be an effect associated with urban or rural residency. MacLennan et al. (1996) found that "people living in country regions were more likely to visit an alternative practitioner than people in metropolitan areas" (p. 572). Fourth, there may be some difference between types of alternative practitioners. For modern and postmodern types of alternative medicine (like homeopathy, natural healing) a more favorable culture may exist in urban areas as opposed to more rural areas. On the other hand, more favorable cultural conditions for traditional types like faith healing may prevail in more rural areas. Finally, there may be an effect of GP attitude towards alternative medicine. Some GPs are more inclined to encourage alternative medicine consultation than others. The gatekeeping role of the general practitioner in the Netherlands does not include alternative medicine. In most health insurance policies in the Netherlands a GP referral is not required to get alternative medicine consultations reimbursed. However, in the Dutch health care system virtually all individuals are registered with a GP and he/she is usually the first point of contact with the health care system. People may therefore act according to their GP's belief about alternative medicine. In addition, Visser (1988) found that GPs who practice alternative medicine more often refer their patients to other alternative practitioners. It was also found that alternative GPs are not equally dispersed over the country. The percentage of GPs practicing alternative medicine is particularly high in the western part of the country (Visser, 1988).

Three types of alternative therapies will be stu- died: homeopathy, paranormal healing and manual therapy (chiropractice). These are the three most common types of alternative medicine in The Netherlands. Homeopathy has clearly the highest degree of acceptance in the general public and in regular medicine. In 1988, about $6 \%$ of the adult population had used homeopathy in the past five years (Foets and Sixma, 1991). Homeopathy was and is covered by public and private insurance policies, provided it is practiced by medical doctors with a regular education. Paranormal healing is the second most common type of alternative healing in the general population (about $3.5 \%$ users in the past five years). Among practitioners of regular medicine, paranormal healing is accepted to a lesser extent than manual therapy and homeopathy and it was (and is) not covered in any insurance policy. It is one of the oldest forms of alternative medicine. Manual therapy is again more 
Verheij, R.A., Bakker, D.H. de, Groenewegen, P.P. Is there a geography of alternative medical treatment in The Netherlands? Health \& Place: 1999, 5(1), 83-97

widely accepted in regular medicine. Like homeopathy this type of therapy can be regarded nivel as more modern than paranormal healing. Just over 3\% of the total adult population had used manual therapy in the past five years in 1988. It was and is covered by public and private insurance policies, provided it is practiced by physiotherapists with conventional education.

\section{[FIGURE 1]}

In this paper we try to assess the variation between places in use of the three types of alternative medicine and to what extent such variations can be explained by level of supply, urbanicity, GP attitude towards alternative medicine or characteristics of individuals. This is done using multilevel logistic regression analysis. We first need to know whether or not there are differences between places at all:

Is there variation between places in alternative medical care utilization? Two types of geographic units are investigated: towns and villages where people live and GP- practices where they are enlisted. Although there is a large overlap between these two levels, they are not the same. One village may be served by more than one GP; one GP may draw his patients from more than one village. If between place variations do exist, we first want to investigate if they are the result of variations in place populations. For example, places or practices with more people between $25-55$ years of age are likely to be high using places. We first need to know, therefore:

To what extent is the variation between places a matter of spatial clustering of individual level characteristics?

Step by step groups of individual level variables will be included in the analyses to investigate the effect of population composition on area variations. In the first step health indicators will be introduced into the model. This is followed by demographic variables, socioeconomic indicators and attitudinal variables. With the attitudinal variables we intend to measure the extent to which people believe their health is just a matter of fate, and whether it can be improved by consulting a professional. Religious and political affiliation is added to the model in the next step. After each step the change in between place variation is assessed. If between place variation diminishes significantly after including a set of individual characteristics it can be concluded that between place variations are in part the result of area composition according to that set of individual characteristics. Having controlled for the individual level variables, there may still be some variation between places left. This variation may be due to urbanicity, supply level and GP attitudes towards alternative medicine.

To what extent can (remaining) variations between areas be explained by urbanicity, level of supply or GP attitudes towards alternative medicine?

With respect to urbanicity, we expect that the more modern types of alternative medicine are more popular in urban areas, whereas the more traditional types are more popular in rural areas. Furthermore, we expect utilization to be higher in places where supply is higher. Finally, we expect utilization to be higher in cases where one's GP has a positive attitude towards alternative medicine.

It is likely that place characteristics and GP attitudes matter more for some categories in the population than for others. Geographic constraints for visiting an alternative practitioner will be more important for some than for others. Some individuals may be more sensitive to the GP's viewpoint than others. These conditional hypotheses are concerned with their relation between expected gain and costs. The central assumption is that the probability of utilization increases with either higher expected gains or lower expected costs.

First, it is hypothesized that place and distance matter less, the more seriously ill one feels. Expected gains from consulting an alternative practitioner will be higher and the decision to visit or not will be less influenced by geo- graphic and other constraints. Access costs will be taken for granted. Suggestions in that direction were found by Girt (1973). We expect that place differences and distance decay effects will be smaller for the more seriously ill. 
Verheij, R.A., Bakker, D.H. de, Groenewegen, P.P. Is there a geography of alternative medical treatment in The Netherlands? Health \& Place: 1999, 5(1), 83-97

Similarly, we expect that GP objections to alternative medicine matter less, the more unhealthy people feel. In cases of serious illness, the costs of acting against the GP's attitude will be taken for granted.

Second, it is hypothesized that variation between places and/or GP practices will be smaller for higher socio-economic groups than for lower socio-economic groups. Several reasons lie behind this hypothesis: higher socio-economic groups will have to invest a smaller portion of their total financial resources in visits to alternative practitioners and will be less hindered by distance and consultation costs; their health attitude is less oriented towards health professionals and they will be less affected by their GP's attitude towards alternative therapies. Thus, two additional questions will be addressed.

- Does level of supply, urbanicity and GP attitudes matter more for those with relatively good perceived health than for those with relatively bad perceived health?

- Does level of supply, urbanicity and GP attitudes matter more for lower socioeconomic groups than for higher socio-economic groups?

\section{Data}

Data were derived from the Dutch National Survey of General Practice, carried out by NIVEL in 1987-1988. Data were gathered in two stages. In the first stage a stratified random sample of 103 general practices was used. In the second stage a random sample of about 100 patients registered with each participating GP was drawn. Practically all Dutch citizens are registered with one specific GP. The original dataset contains information on 13,014 individuals listed with 103 general practices, living in about 400 towns or villages (Foets et al., 1992). The percentage of users in the past 12 months of alternative medicine amounts to $7.4 \%$ in the original dataset1. This figure is somewhat higher than found in the health interview survey of the Dutch Central Bureau of Statistics (Verweij, 1992) (5.6\%) and somewhat lower than in data collected in 7 public health regions in the Netherlands (Van Loon, 1992) (8.6\%). Excluded from the analyses were age groups younger than $15(\mathrm{n}=2227)$ and subjects with missing values on any of the dependent and independent variables $(\mathrm{n}=1944)$. Herewith the total dataset contains a total number of 8843 patients, living in 393 settlements (towns, villages), listed with 192 general practitioners in 103 general practices. Variables used in the analyses are listed in Fig. 2. Besides the level of patients, data were available at two higher levels: GP practice and place (town, village, hamlet) of residence. Patients typically live within a rather short distance from their GP. In 1990 only $6.3 \%$ of the total population did not have a GP in their place of residence (Van Dam, 1995). However, there is not a one-to-one relation between settlement of residence and GP practice. Some settlements are served by more than one GP practice, some GP practices serve more than one settlement. There are more settlements than GP practices in the sample.

At the level of settlements distance to nearest alternative practitioner was used as an indicator of level of supply. These distances were computed as follows. Settlements of patients in the sample were determined on the basis of four- digit postcodes. Larger settlements with more than one three-digit postcode were subdivided in three-digit postcode regions. Postcodes of alternative practitioners were obtained from the Foundation for Natural Wellbeing (1988).

Subsequently, road distances from patient settlements to the nearest settlement with a homeopath, paranormal healer and manual therapist were calculated 2 with aid of a digital roadmap and software developed at the University of Utrecht (Huigen and De Vocht, 1993; Van Dam, 1995). The quality of the supply data is debatable. However, there is no reason to believe that there are systematic discrepancies with real levels of supply. Furthermore, since the address data are used by potential users of alternative medicine, it can be argued that providers not listed with the Foundation of Natural Wellbeing affect utilization to a lesser extent. Urbanicity (based on address-density in a municipality) (Den Dulk et al., 1992) was also measured at the level of settlements. 
At the level of GP practices information was available on the GP's attitude towards alternative medicine. All GPs participating in the study completed a questionnaire. Questions were included concerning attitudes towards alternative medicine (five-point scale), referrals to and practicing of alternative medicine (no; only at patient's request; also at own initiative). In case of group and duo-practices individual patients could not be assigned to individual doctors. Therefore, the data were aggregated to practice level. Practices were assigned a positive attitude towards alternative medicine in cases where at least one of the practitioners had this attitude. At the patient level, a distinction is made between demographic factors, socio-economic factors, health and attitudinal factors and religious and political affiliations. Health indicators include self-evaluated general health (dichotomized with cut-o. point 'less than good'); com- plaints (sumscore of a 43-item list dichotomized into $\leq 2$ and $>2$ ); the presence of serious, minor and intermediate chronic conditions (dichotomies). Also included were the General Health Questionnaire (Goldberg, 1972), measuring the likelihood of psychiatric disorders and the BIOPRO-scale (Hodiamont, 1986), measuring the presence of psychosocial problems. Three measures of health locus of control were avail- able in the dataset: internal orientation, chance orientation and provider orientation. The measures indicate the extent to which health problems are regarded as determined by the individual, as a matter of fate or as a problem of a health care provider. Among the demographic variables gender and age between 25 and 54 were included. Two socio-economic factors are taken into account: education (high vs. rest) and insurance (public vs. private). Furthermore the Nijmegen expectation scale (Van de Lisdonk, 1985) was used to measure the extent to which people are inclined to seek (regular) medical care. Finally, information was available on voting (voting for environmentalist parties) behavior and religious affiliation (Roman Catholic vs. rest). All scales were transformed into Z-scores in the multilevel analyses.

Dependent variable was utilization in the past 5 years of homeopathy, paranormal healing and manual therapy. The rather long time period was employed to increase utilization frequencies.

\section{[FIGURE 2]}

\section{METHODS}

Multilevel logistic regression models are used to analyze the data. Multilevel models "have conceptual advantages over other methods of analysis because of their ability to evaluate the degree of... variability between areas before the inclusion of additional explanatory variables... in the model" (Ecob, 1996, p. 62). When the degree of variability between areas decreases with the inclusion of an individual level independent variable, it can be deduced that between area variations are in part a result of differences in composition according to these individual level variables. It also means that $Ð$ if this particular variable is omitted $\mathrm{D}$ we are in fact not seeing between place variations, but variations between the people living in these places. Multilevel analyses were carried out with $\mathrm{MLn}^{3}$ (for an example based on dichotomous dependent variables, see Paterson, 1995).

The modelling proceeded as follows. Having two geographic levels (settlement and GP practice) present in the data, it is necessary to deter- mine whether or not they are both needed in the analyses. To identify the relative importance of each level, first a three-level cross-classified model was analyzed, such as depicted in Fig. 3 (Duncan et al., 1996). A cross-classified model was necessary because the three levels are not hierarchically nested. At this stage only the constant was included in the model, as it only served to assess the variability at these two levels. The subsequent analyses were carried out only with the levels having significant variability.

In the next steps sets of individual level explanatory variables were included in the model. Health indicators, demographic, socio-economic and attitudinal characteristics, religious/political affiliations were subsequently introduced in the model. This approach 
makes it possible to assess the change in between place variability after inclusion of each setnivel and the contribution of each set of independent variables to the between place variability. Having established the richest individual level model in this manner, higher level effects are tested in the model to see whether they bind the remaining between place variability. First, urbanicity is included in the model, followed by GP attitudinal and level of supply variables. Until this point there is only one random term in the model. MLn offers the possibility to split this random variation between groups in the population which is useful to investigate for instance whether between practice variability is the same between subgroups of the population. Between place variation can be determined for different subgroups. This was done for level of education, type of insurance and perceived health status.

\section{RESULTS}

\section{The overall relevance of place}

As a first step in the analyses we tried to assess the relative variability at each of the two geo- graphic levels (settlement, GP practice), com- pared with the individual level. A threelevel cross classified model was constructed (Fig. 3). This was necessary because the three levels are not hierarchically nested. No explanatory variables are included in the model yet. The results are presented in Table $1^{4}$. In the fixed part of the model the coefficient of the constant is given. This estimate represents the log-odds of the general mean percentage of users. In the random part the estimates of the variation at each of the three levels is given. With respect to homeopathy and manual therapy it can be observed that variation between practices is much larger than between settlements. A considerable amount of variation in homeopathy and manual therapy use is located at the GP practice level. With respect to paranormal healing there is only a small amount of variability at the two higher levels. With respect to homeop- athy and manual therapy, the variation between GP practices is significant, being more than two times its standard error. This is clearly not the case with paranormal healing. In order to save computation time and facilitate interpretation, a hierarchical two-level structure was assumed in the subsequent analyses, with GP practice at the higher level (Fig. 4). In these two-level analyses urbanicity of the practice location was used instead of the patient's place of residence.

\section{[TABLE 1] [FIGURE 4]}

\section{Homeopathy}

In order to investigate to what extent the variability between GP practices is a matter of differences in health of the practice population, we started extending the model with health indicators. Subsequently, the model was extended with individual demographic, socioeconomic, attitudinal and religious/political characteristics, followed by urbanicity, GP characteristics and supply. Estimates and standard errors are provided in Appendix A. Minor chronic conditions, relatively bad perceived health and the presence of more than two selfreported complaints significantly increase the likelihood of homeopath consultation. Between practice variation increases from 0.11 to 0.14 . Both demographic variables included in the next step have a significant effect as well. The same applies to higher education and type of insurance. Through these steps between practice variance remains virtually the same. A decline (to 0.11 ) occurs when patient's attitudes are included in the model. Individuals who are to a larger extent (lower scores) inclined to attribute their health to chance and health care provider, tend to have visited a homeopath more often. Inclusion of these variables also renders socio-economic factors insignificant. A further decline in between practice variation occurs when religion is included in the model. Roman Catholics less frequently visit a homeopath. In the following step urbanicity does decrease between practice variation, without having a significant effect in itself. Surprisingly, GP attitude towards alternative medicine, nor distance to nearest homeopath has a significant contribution to the 
Verheij, R.A., Bakker, D.H. de, Groenewegen, P.P. Is there a geography of alternative medical treatment in The Netherlands? Health \& Place: 1999, 5(1), 83-97

model. In the final model between practice variation has decreased to 0.05 and is no longer nivel significant. In analyses splitting the level-2 variance between subgroups in the population (according to insurance and health status) no significant level-2 variation was found (results not in table).

\section{Paranormal healing}

With respect to paranormal healing estimates and standard errors are provided in Appendix B. Perceived general health, minor chronic conditions and complaints each have a significant contribution to the model, without decreasing the initial between practice variation. The same is true for age and gender. So far results are similar to those with respect to homeopathy. However, education and insurance do not have a significant effect. Concerning attitudes, only chance orientation scale has a significant positive effect, indicating that people who attribute their health to chance to a lesser extent, tend to visit paranormal healers more often. Thus far, between GP practice variation remains high. This situation changes dramatically with the inclusion of religion in the model. Roman Catholics are much more inclined to visit paranormal healers than other religions (mainly protestant) and between practice variation drops to insignificant values. No effects are found of urbanicity, GP characteristics and distance. In analyses splitting the level-2 variance between subgroups in the population (according to insurance and health status) no significant level-2 variation was found (results not in table).

\section{Manual therapy}

Estimates and standard errors with respect to manual therapy are provided in Appendix C. Complaints, intermediate and minor chronic conditions have a positive effect on the utilization of manual therapy, without decreasing level-2 variation. Level-2 variation is not affected by demographic characteristics either, although there is a significant effect of age (not of gender). Higher education, and private insurance exert the expected positive effect and level-2 variation drops somewhat. The same applies to attitudinal variables. There is a significant positive association between lower expectations of (regular) health care providers (higher scores) and a higher likelihood of visiting a manual therapist. Unlike homeopathy and paranormal healing, religion is of no importance, whereas there is some effect of urbanicity. The latter is hard to interpret. Small and medium sized towns have higher utilization figures than the 'deep' rural areas. Level-2 variation drops somewhat further with inclusion of GP attitudes. Patients of GPs who practice some kind of alternative medicine have a lower probality of manual therapy utilization. Again distance has no effect. The remaining between place variation was split between subgroups of individuals (results not in table).

This remaining between place variation appears to be exclusively present among individuals in rather good health. This is consistent with our hypothesis that geographic constraints and GP characteristics matter more for those in relatively good health. To explore this hypothesis further, interaction terms were included in the model. No evidence was found for a differential effect of GP attitude according to patient perceived health. Interaction terms of perceived health with urbanicity, perceived health with distance did not produce significant coefficients either. Differential level-2 variability was not found between public and privately insured people, nor higher and lower educated. This leads to the conclusion that we do know that level-2 characteristics are more important for the healthy individual, but that we do not know which level-2 characteristics are concerned.

\section{CONCLUSION AND DISCUSSION}

In this paper we have tried to assess the amount and nature of variation between places with respect to the use of three types of alternative medicine: homeopathy, paranormal healing and manual therapy. Three levels were present in the data: the GP practice level, the settlement level and the individual level. In the first step of our analyses the relevance of the 
Verheij, R.A., Bakker, D.H. de, Groenewegen, P.P. Is there a geography of alternative medical treatment in The Netherlands? Health \& Place: 1999, 5(1), 83-97

two higher levels was tested. It was concluded that the settlement level is not very useful, $\frac{7}{\text { nivel }}$ once the GP practice level is taken into account. This does not necessarily mean that characteristics of GP practices are more important than characteristics of the area where they are located. Indeed, this finding may be due to the two-stage study design (stratified sample of GPs, followed by random sample of registered patients), which results in a greater dispersion of GP practices than of settlements. Settlements are typically located around a GP practice. According to Goldstein (1995) the disappearance of between settlement variations with the inclusion of the level of GP practices is not exceptional: "such an effect will often be observed where one classification has far fewer units than another. In such circumstances we need to be careful about our interpretation of the relative sizes of the variances". On the other hand, one could argue that there is truly a geography of GP practices rather than of settlements. This problem proved to be not very relevant, however, given the results of the subsequent analyses. These analyses, including only the patient level and the GP practice level, ultimately suggest that contextual variations indicate mainly a geography of patients. In the two-level analyses considerable between practice variation appeared to exist in all three types of alternative medicine. Based on literature findings a number of individual level variables were included in the model to see whether this variability is a matter of practice composition. There are significant effects of perceived health, minor chronic conditions and the presence of complaints on the utilization of each type of alternative medicine. Serious chronic conditions as well as social and psychiatric problems are not associated with alternative care utilization. Women have a higher utilization probability of homeopathy and paranormal healing, but not of manual therapy, whereas being between 25 and 54 years of age increases the probability of all three types (in comparison with older and younger age groups). Higher education and private insurance positively affect utilization of homeopathy and manual therapy, but are not associated with paranormal healing. This finding might be related to the fact that manual therapy and homeopathy are the more 'modern', down-to-earth types, whereas paranormal healing is a 'premodern' and more mystical type of treatment. The three types of alternative medicine have in common that lower expectations of health care providers increase alternative medicine utilization. Political affiliation appears not to be relevant. This can not be said of religious affiliation, which has a strong effect on the utilization of homeopathy and particularly paranormal healing. Paranormal healing is more popular among Roman Catholics, while homeopathy is more in fashion among protestants. Between practice variations in manual therapy appear to be explained by practice composition to a limited extent. An intermediate position is taken by homeopathy. The geography of paranormal healing appears to be entirely a matter of practice composition according to religion. In the Netherlands, Catholicism is concentrated in the south and east, whereas protestants dominate in the rest of the country. Furthermore, Dutch society was organized along strict religious lines for many decades, possibly also implying that protestant patients concentrate with protestant doctors and Catholic patients with Catholic doctors. The fact that religion is a very important factor in the utilization of paranormal healing may be related to its premodern nature.

Higher level variables have no significant effect on the utilization of homeopathy and paranormal healing. With respect to the effect of GP attitudes, similar results were found by Visser (1988) and it must be concluded that there is little a GP can do to affect patient behavior with respect to alternative medicine. We had expected that higher degree of urbanization would be positively associated with higher utilization of homeopathy and manual therapy and negatively with paranormal healing. This appeared not to be the case. Although there is a significant effect in manual therapy utilization, it is not really in the direction supposed. GP's attitudes matter only with respect to manual therapy utilization. Patients of GPs who apply some kind of alternative medicine seem to be less inclined to visit a manual therapist. This negative effect is counter to our expectations. It may be a reflection of the fact that manual therapy is the least 'alternative' type of alternative medicine. In some countries manual therapy (chiropractice) is regarded as regular medicine (US, Great Britain). 
Verheij, R.A., Bakker, D.H. de, Groenewegen, P.P. Is there a geography of alternative medical treatment in The Netherlands? Health \& Place: 1999, 5(1), 83-97

GPs favoring alternative medicine may even regard it as not alternative and discourage utilization. Level of supply does not have any effect on utilization. Patient decisions to seek alternative medical care are not influenced by geographic proximity. According to Walmsley (1988, p. 95), "the friction of distance appears to be greater for relatively obligatory travel such as the journey to work than for relatively discretionary activities such as entertainment". This is in line with our finding that alternative medical treatment is used by relatively wellto-do people with minor health problems, who do not believe in regular medicine. Only in the case of manual therapy a significant amount of level-2 variation remained after including individual, GP and place characteristics in the model. This variation appeared to be exclusively present among individuals with rather good perceived health, in line with our hypothesis that level-2 characteristics are more important for healthy individuals. Several cross-level interactions of perceived health with urbanicity, distance and GP attitudes were tested, none of which appeared to be significant. The general picture for homeopathy and paranormal healing is that, once people have decided on the basis of personal characteristics that they want it, contextual circumstances are irrelevant. With respect to manual therapy we suspect that higher level, nonindividual factors do play a role, especially for the relatively healthy, but we are left empty handed as to what specific factors they might be.

\section{ACKNOWLEDGEMENTS}

This study was supported by a grant from the Netherlands Organization for Scientific Research. The authors would like to thank Peter Spreeuwenberg for his valuable comments on an earlier version of this paper.

\section{Appendix A}

See Table 2.

\section{Appendix B}

See Table 3.

\section{Appendix C}

See Table 4.

\section{[TABLE 2] [TABLE 3] [TABLE 4]}

\section{REFERENCES}

Foundation for Natural Wellbeing, 1988. Adressengids Alternatieve Genezers 1987-1988. Stichting Natuurlijk Welzijn, Epe.

Van Dam, F., 1995. Meer voor Minder: Schaalverandering en Bereikbaarheid van Voorzieningen in Landelijke Gebieden in Nederland. Faculteit Ruimtelijke Wetenschappen, Utrecht.

Den Dulk, C.J., Stadt, H., Vliegen, J.M., 1992. Een nieuwe maatstaf voor stedelijkheid: de omgevingsadressen dichtheid [A new measure for the degree of urbanization: the address density of the surrounding area]. In: Maandstatistiek van de bevolking, No. 7, pp. 14-22.

Duncan, C., Jones, K., Moon, G., 1996. Health-related behavior in context: a multilevel modelling approach. Social Science \& Medicine 42, 817-830.

Ecob, R., 1996. A multilevel modelling approach to examining the effects of area of residence on health and functioning. Journal of the Royal Statistical Society 159, 61-75.

Fleuren, M.A.H., Vermulst, A.A., Schouwink, I., Persoon, J.M.G., 1990. Tevredenheid bij gebruikers van alternatieve geneeswijzen: determinanten van tevredenheid. TSG 68 , 335340.

Foets, M., Van der Velden, J., De Bakker, D.H., 1992. Dutch National Survey of General Practice: Survey design. NIVEL, Utrecht. 
Verheij, R.A., Bakker, D.H. de, Groenewegen, P.P. Is there a geography of alternative medical treatment in The Netherlands? Health \& Place: 1999, 5(1), 83-97

Foets, M., Sixma, H., 1991. Een Nationale Studie van Ziekten en Verrichtingen in de $\frac{7}{\text { niver }}$ Huisartspraktijk. Basisrapport: Gezondheid en Gezondheidsgedrag in de Praktijkpopulatie. NIVEL, Utrecht.

Frenken, F.J.M., 1990. Regional data from the 1985/1988 Health Interview Surveys.

Maandbericht Gezondheids-statistiek, January, pp. 4-20.

Fulder, S., Munro, R., 1985. Complementary medicine in the UK: patients, practitioners and consultations. The Lancet September 7, 2, 542-545.

Furnham, A., Smith, C., 1988. Choosing alternative medicine: a comparison of the beliefs of patients visiting a general practitioner and a homeopath. Social Science \& Medicine 26, 685-689.

Girt, J.L., 1973. Distance to general medical practice and its effect on revealed ill-health in a rural environment. Canadian Geographer 17, 154-166.

Goldbeck-Wood, S., Lie, L.G., Yamauchi, M., Zinn, C., Josefson, D., Ingram, M., 1996. Complementary medicine is booming worldwide. British Medical Journal 313, 131-133.

Goldberg, D.P., 1972. The detection of psychiatric illness by questionnaire. In: Mandsley Monographs No. 21. Oxford University Press, London.

Goldstein, H., 1995. Multilevel cross classification. In: Multilevel Statistical Models. Edward Arnold, London, pp. 113-122.

Hodiamont, P.P.G., 1986. Het Zoeken naar Zieke Zielen: een Onderzoek in het Kader van de Sociale Psychiatrie. Katholieke Universiteit Nijmegen, Nijmegen.

Huigen, P.P.P., De Vocht, A.G.A., 1993. Bereikbaarheidsanalyse Voortgezet Onderwijs. FRW, Universiteit Utrecht, Utrecht.

Kleijnen, J., Ter Riet, G., Knipschild, P., 1993. Effectiviteit van Alternatieve Geneeswijzen: een Literatuuronderzoek. Rijksuniversiteit Limburg, Maastricht.

Knipschild, P., Kleijnen, J., Ter Riet, G., 1990. Belief in the efficacy of alternative medicine among general practitioners in the Netherlands. Social Science \& Medicine 31, 625-626.

Limberger, H.H.B., Mackenbach, J.P., Ooijendijk, W.Th.M., 1981. Het gebruik van alternatieve geneeswijzen in Nederland. TSG 59, 219-225.

Van de Lisdonk, E.H., 1985. Ervaren en Aangeboden Morbiditeit in de Huisartspraktijk: een Onderzoek met Dagboeken. Katholieke Universiteit Nijmegen, Nijmegen.

Van Loon, A.J.M., 1992. Leefstijl en Gezondheid: Resultaten van Regionale Gezondheidsenquetes Vergeleken. Landbouwuniversiteit Wageningen, Wageningen.

MacLennan, A.H., Wilson, D.H., Taylor, A.W., 1996. Prevalence and cost of alternative medicine in Australia. The Lancet 347, 569-573.

Ministry of Health, Welfare and Sports, 1996. Speech by the Minister of Health, Welfare and Sports, Mrs. dr. E. Borst- Eilers, 27 March (unpubl.).

Paterson, L., 1995. Entry into university by school leavers. In: Woodhouse, G. (Ed.), A Guide to MLn for new Users. Institute of Education, University of London, London, pp. 87-101.

Shekelle, P.G., Markovich, M., Louie, R., 1995. Factors associated with choosing a chiropractor for episodes of back bain care. Med. Care 33, 842-850.

Van der Smagt, C.P., 1988. Nog eens alternatieve geneeswijzen. Medisch Contact 43, 12811284.

Spigelblatt, L., Laine-Ammara, G., Pless, I.B., Guyver, A., 1994. The use of alternative medicine by children. Pediatrics 94, 811-814.

Verweij, G.C.G., 1992. Developments in consultation of alternative (general) practitioners, 1985-1990. Maandbericht Gezondheidsstatistiek 92 (5), 4-11.

Visser, G.J., 1988. Huisartsen en Alternatieve Geneeswijzen: een Onderzoek naar Meningen en Ervaringen van Huisartsen en PatieÈ nten. NIVEL, Utrecht.

Visser, G.J., Peters, L., 1990. Alternative medicine and general practitioners in the Netherlands: towards acceptance and integration. Family Practice 7, 227-232.

Visser, G.J., Peters, P., 1994. Samenwerking van Huisartsen en Alternatieve Therapeuten: Evaluatie van twee Experimenten. NIVEL, Utrecht.

Walmsley, D.J., 1988. Urban Living: the Individual in the City. Longman, New York.

Van Wijk, M.C.W., Eenink, G.E.M., De Waart, F.G., Van Loon, A.J.M., Schouten, E.G., 1995. Gebruik van alterna-

tieve geneeswijzen en chronische aandoeningen: de associatie nader bekeken. TSG 73, 8389. 
Verheij, R.A., Bakker, D.H. de, Groenewegen, P.P. Is there a geography of alternative medical treatment in The Netherlands? Health \& Place: 1999, 5(1), 83-97

\section{FIGURES AND TABLES}

$\%$ contact

2.3 to 4.2

4.2 to 4.7

4.7 to 5.3

5.3106 .6

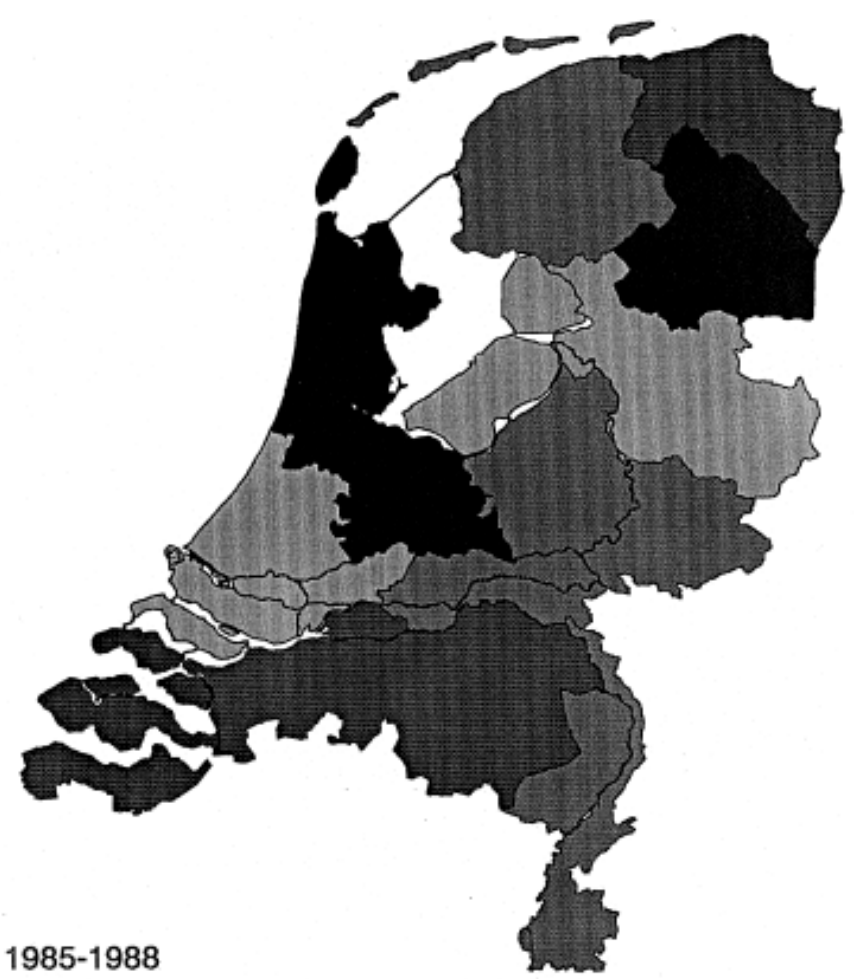

CBS health interview survey 1985-1988

Fig. 1. Percentage of population consulting alternative practitioner in past 12 months by province (adapted from Frenken, 1990).

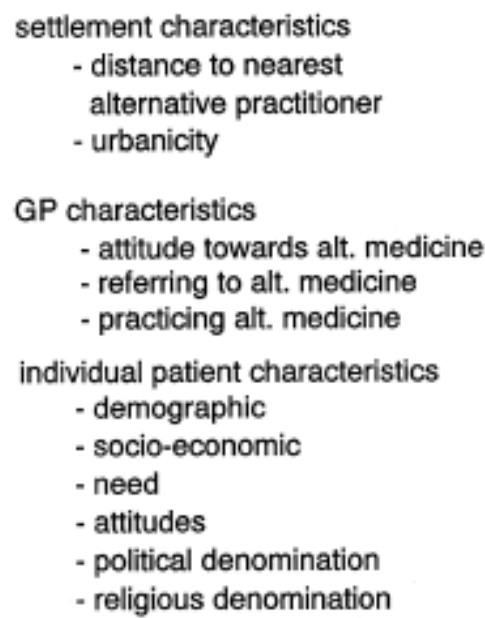

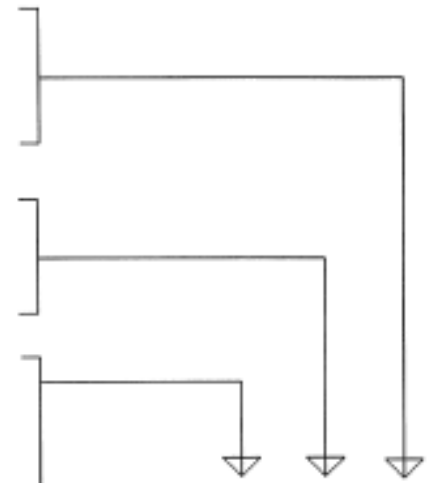

alternative medical care utilization

Fig. 2. Variables and their levels used in the analyses. 
Verheij, R.A., Bakker, D.H. de, Groenewegen, P.P. Is there a geography of alternative medical treatment in The Netherlands? Health \& Place: 1999, 5(1), 83-97

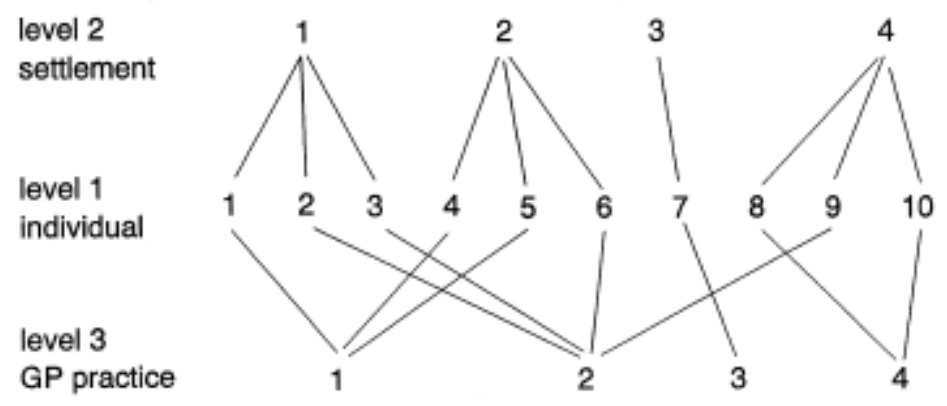

Fig. 3. Cross classified structure. Adapted from (Duncan et al., 1996).

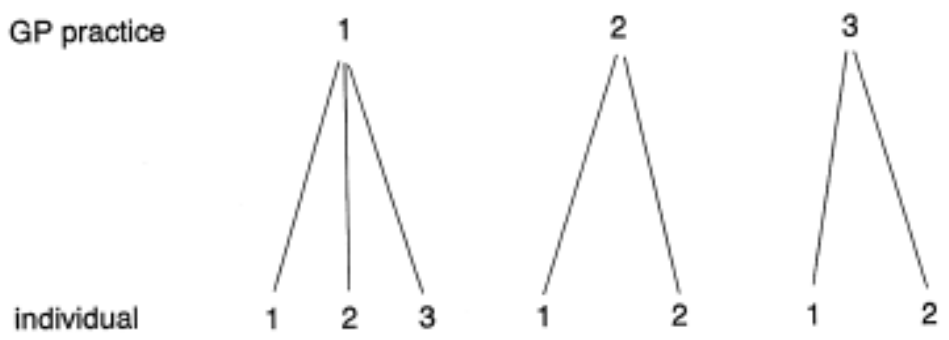

Fig. 4. Two-level structure. Adapted from (Duncan et al., 1996). 
Verheij, R.A., Bakker, D.H. de, Groenewegen, P.P. Is there a geography of alternative medical treatment in The Netherlands? Health \& Place: 1999, 5(1), 83-97

Table 1

Results cross-classified model

\begin{tabular}{lccc}
\hline & Homeopathy & Paranormal healing & Manual therapy \\
\hline $\begin{array}{l}\text { Fixed } \\
\text { Individual constant }\end{array}$ & $-2.949(0.0633)$ & $-3.395(0.0923)$ & $-3.612(0.0904)$ \\
& & & \\
randam & $0.0160(0.0600)$ & $0.0978(0.1062)$ & $0.0432(0.1269)$ \\
settlement constant & $\mathbf{0 . 1 6 8 3 ( 0 . 0 8 2 9 )}$ & $0.0794(0.0923)$ & $\mathbf{0 . 2 6 5 3 ( 0 . 1 2 8 2 )}$ \\
$\begin{array}{l}\text { GP practice constant } \\
\text { individual constant }\end{array}$ & $\mathbf{0 . 9 6 0 9 ( 0 . 0 1 4 2 )}$ & $\mathbf{1}(0)$ & $\mathbf{1}(0)$ \\
\hline
\end{tabular}


Log-odds of utilization of homeopathy in past 5 years

\begin{tabular}{|c|c|c|c|c|c|c|c|c|c|}
\hline & \multicolumn{9}{|c|}{ Results multilevel analyses } \\
\hline & 0 model & + health & $\begin{array}{l}\text { + demo- } \\
\text { graphics }\end{array}$ & $\begin{array}{l}\text { + sodio- } \\
\text { economic }\end{array}$ & + attitudes & $\begin{array}{l}\text { + religion/ } \\
\text { pobitics }\end{array}$ & + urbanicity & $\begin{array}{l}\text { + GP charac- } \\
\text { teristics }\end{array}$ & + distance \\
\hline \multicolumn{10}{|l|}{ Fixed } \\
\hline Constant & $-2.908(0.061)$ & $-3.54(0.10)$ & $-4.131(0.14)$ & $-4.132(0.16)$ & $-4.135(0.16)$ & $-4.01(0.16)$ & $-4.008(0.19)$ & $-3.903(0.28)$ & $-3.851(0.29)$ \\
\hline $\begin{array}{l}\text { Self-evaluated health less } \\
\text { than good }\end{array}$ & & $0.3973(0.13)$ & $\mathbf{0 . 4 7 6 2 ( 0 . 1 3 )}$ & $\quad 0.5361(0.13)$ & $0.6442(0.13)$ & $\quad 0.6377(0.13)$ & $0.638(0.13)$ & $0.6392(0.13)$ & $0.6407(0.13)$ \\
\hline$\geq 1$ serious chr. cond. ${ }^{\circ}$ & & $-0.0607(0.13)$ & $0.0816(0.13)$ & $0.1247(0.13)$ & $0.1929(0.13)$ & $0.2044(0.13)$ & $0.2126(0.13)$ & $0.2145(0.13)$ & $0.2132(0.13)$ \\
\hline$>1$ intermed. chr. cond. ${ }^{c}$ & & $0.1058(0.11)$ & $0.0936(0.11)$ & $0.1297(0.11)$ & $0.203(0.11)$ & $0.2064(0.11)$ & $0.2064(0.11)$ & $0.2035(0.11)$ & $0.2033(0.11)$ \\
\hline$>1$ minor chr. conditions & & $0.5668(0.10)$ & $0.4812(0.10)$ & $0.4886(0.10)$ & $0.4837(0.10)$ & $0.4911(0.10)$ & $0.4889(0.10)$ & $0.4885(0.10)$ & $0.4877(0.10)$ \\
\hline$\geq 2$ complaints & & $0.518(0.11)$ & $0.4521(0.11)$ & $0.4519(0.11)$ & $\mathbf{0 . 4 2 5 1}(0.12)$ & $0.4134(0.12)$ & $\mathbf{0 . 4 1 8 8}(0.12)$ & $0.4166(0.12)$ & $0.4155(0.12)$ \\
\hline GHQ & & $0.0757(0.05)$ & $0.0603(0.05)$ & $0.0666(0.05)$ & $0.0718(0.05)$ & $0.0757(0.05)$ & $0.0742(0.05)$ & $0.0744(0.05)$ & $0.0742(0.05)$ \\
\hline BIOPRO & & $0.0915(0.05)$ & $0.0817(0.05)$ & $0.0684(0.05)$ & $0.0693(0.05)$ & $0.0641(0.05)$ & $0.0717(0.05)$ & $0.0734(0.05)$ & $0.0729(0.05)$ \\
\hline Female & & & $\mathbf{0 . 5 7 0 2}(0.10)$ & $0.5746(0.10)$ & $0.5715(0.11)$ & $\mathbf{0 . 5 7 3 5}(0.11)$ & $0.5839(0.11)$ & $0.5836(0.11)$ & $0.5837(0.11)$ \\
\hline Age $25-54$ & & & $0.4817(0.10)$ & $0.4576(0.10)$ & $0.3611(0.11)$ & $0.3653(0.11)$ & $0.3663(0.11)$ & $0.3635(0.11)$ & $0.3642(0.11)$ \\
\hline Education high & & & & $0.3936(0.11)$ & $0.203(0.12)$ & $0.1795(0.12)$ & $0.2063(0.12)$ & $0.2102(0.12)$ & $0.208(0.12)$ \\
\hline Public insurance & & & & $-0.2334(0.11)$ & $-0.1931(0.11)$ & $-0.1986(0.11)$ & $-0.2026(0.11)$ & $-0.2046(0.11)$ & $-0.202(0.11)$ \\
\hline $\begin{array}{l}\text { Provider heatth locus of } \\
\text { control }^{2}\end{array}$ & & & & & $0.1791(0.07)$ & $0.1803(0.07)$ & $0.1787(0.07)$ & $0.1794(0.07)$ & $0.1803(0.07)$ \\
\hline $\begin{array}{l}\text { Chance health locus of } \\
\text { control }^{2}\end{array}$ & & & & & $\mathbf{0 . 2 1 4 9}(0.06)$ & $\mathbf{0 . 2 0 1 5}(0.06)$ & $0.201(0.06)$ & $0.1996(0.06)$ & $0.1993(0.06)$ \\
\hline $\begin{array}{l}\text { Internal health locus of } \\
\text { control }^{2}\end{array}$ & & & & & $-0.0115(0.05)$ & $-0.0126(0.05)$ & $-0.0143(0.05)$ & $-0.0157(0.05)$ & $-0.0163(0.05)$ \\
\hline $\begin{array}{l}\text { Nijmegen expectation } \\
\text { of GP Scale }\end{array}$ & & & & & $0.1065(0.06)$ & $0.0994(0.06)$ & $0.102(0.06)$ & $0.104(0.06)$ & $0.1024(0.06)$ \\
\hline Roman Catholic & & & & & & $-0.3395(0.11)$ & $-0.37(0.11)$ & $-0.3689(0.11)$ & $-0.3561(0.12)$ \\
\hline Environmentalist & & & & & & $0.2149(0.21)$ & $0.275(0.21)$ & $0.2846(0.21)$ & $0.2823(0.21)$ \\
\hline Very strongly urban ${ }^{b}$ & & & & & & & $-0.3542(0.20)$ & $-0.2912(0.21)$ & $-0.3408(0.22)$ \\
\hline Strongly urban ${ }^{b}$ & & & & & & & $-0.0887(0.19)$ & $-0.0639(0.19)$ & $-0.1003(0.20)$ \\
\hline Intermediately urban ${ }^{b}$ & & & & & & & $0.1523(0.16)$ & $0.17(0.16)$ & $0.1622(0.16)$ \\
\hline Little urban ${ }^{6}$ & & & & & & & $0.0427(0.17)$ & $0.0815(0.17)$ & $0.0739(0.17)$ \\
\hline $\begin{array}{l}\text { GP practicing alternative } \\
\text { medicine }\end{array}$ & & & & & & & & $0.0268(0.07)$ & $0.0288(0.07)$ \\
\hline $\begin{array}{l}\text { GP inclination to refer to } \\
\text { atternative medicine }\end{array}$ & & & & & & & & $0.1097(0.10)$ & $0.1014(0.10)$ \\
\hline $\begin{array}{l}\text { GP attitude towards } \\
\text { alternative medicine }\end{array}$ & & & & & & & & $-0.137(0.09)$ & $-0.1313(0.09)$ \\
\hline Distance to nearest & & & & & & & & & $-0.0055(0.01)$ \\
\hline \multirow{2}{*}{\multicolumn{10}{|c|}{$\begin{array}{l}\text { homeopath } \\
\text { Random }\end{array}$}} \\
\hline & & & & & & & & & \\
\hline GP practice level & $0.1173(0.05)$ & $0.1442(0.05)$ & $0.1401(0.05)$ & $0.1419(0.05)$ & $0.1098(0.05)$ & $0.0796(0.04)$ & $0.05894(0.04)$ & $0.05089(0.04)$ & $0.0469(0.04)$ \\
\hline Individual level & $1(0)$ & $1(0)$ & $1(0)$ & $1(0)$ & $1(0)$ & $1(0)$ & $1(0)$ & $1(0)$ & $1(0)$ \\
\hline
\end{tabular}

Level 1 is individual, level 2 GP practice. Standard errors in parentheses. ${ }^{2}$ Higher scores indicate lesser orientation/expectation. ${ }^{b}$ eference category 'not urban'. ${ }^{2}$ Reference category 'no chronic condition'. 
Table 3

Log-odds of utilization of paranormal healing in the past 5 years

\begin{tabular}{|c|c|c|c|c|c|c|c|c|c|}
\hline & \multicolumn{9}{|c|}{ Results multilevel analyses } \\
\hline & 0 model & + health & $\begin{array}{l}\text { + demo- } \\
\text { graphics }\end{array}$ & $\begin{array}{l}\text { + socio- } \\
\text { economic }\end{array}$ & + attitudes & $\begin{array}{l}\text { + religion/ } \\
\text { politics }\end{array}$ & + urbanicity & $\begin{array}{l}+ \text { GP charac- } \\
\text { teristics }\end{array}$ & + dis-tance \\
\hline \multicolumn{10}{|c|}{ (3) } \\
\hline Constant & $-3.362(0.07)$ & $-4.158(0.12)$ & $-4.664(0.17)$ & $-4.545(0.19)$ & $-4.541(0.19)$ & $-4.783(0.20)$ & & $-4.567(0.33)$ & $-4.627(0.36)$ \\
\hline $\begin{array}{l}\text { Selfevaluated health less } \\
\text { than good }\end{array}$ & & $0.6012(0.15)$ & $\mathbf{0 . 6 6 7 1 ( 0 . 1 5 )}$ & $0.6817(0.15)$ & $0.7913(0.15)$ & $\quad 0.7978(0.15)$ & $0.8002(0.15)$ & $0.8015(0.15)$ & $0.8003(0.15)$ \\
\hline Serious chr. cond. & & $-0.2566(0.15)$ & $-0.1315(0.15)$ & $-0.1165(0.15)$ & $-0.0640(0.15)$ & $-0.0885(0.16)$ & $-0.0816(0.16)$ & $-0.0803(0.16)$ & $-0.0796(0.16)$ \\
\hline Intermed. chr. cond. ${ }^{c}$ & & $0.2247(0.13)$ & $0.2212(0.13)$ & $0.2183(0.13)$ & $0.2856(0.13)$ & $\quad 0.2809(0.13)$ & $0.2825(0.13)$ & $0.2809(0.13)$ & $0.2816(0.13)$ \\
\hline Minor chr. conditions ${ }^{c}$ & & $0.6145(0.12)$ & $0.5509(0.12)$ & $0.551(0.12)$ & $0.55(0.12)$ & $0.5432(0.12)$ & $0.5403(0.12)$ & $0.5419(0.12)$ & $0.5417(0.12)$ \\
\hline$\geq 2$ complaints & & $0.6258(0.14)$ & $0.5854(0.14)$ & $0.5946(0.14)$ & $0.5704(0.14)$ & $\quad 0.5789(0.14)$ & $0.585(0.14)$ & $0.5845(0.14)$ & $0.5845(0.14)$ \\
\hline GHQ & & $0.0442(0.05)$ & $0.0362(0.05)$ & $0.0372(0.05)$ & $0.0412(0.05)$ & $0.0319(0.05)$ & $0.0316(0.05)$ & $0.0321(0.05)$ & $0.0324(0.05)$ \\
\hline BIOPRO & & $0.1(0.06)$ & $0.084(0.06)$ & $0.0841(0.06)$ & $0.0851(0.06)$ & $0.0804(0.06)$ & $0.0861(0.06)$ & $0.0862(0.06)$ & $0.0860(0.06)$ \\
\hline Female & & & $0.3822(0.12)$ & $0.3901(0.123)$ & $0.3941(0.13)$ & $0.3779(0.13)$ & $0.3833(0.13)$ & $0.3826(0.13)$ & $0.3821(0.13)$ \\
\hline Age $25-54$ & & & $0.5002(0.13)$ & $0.4957(0.13)$ & $0.4116(0.13)$ & $\quad 0.3875(0.13)$ & $0.384(0.13)$ & $0.3804(0.13)$ & $0.38(0.13)$ \\
\hline Education high & & & & $-0.0153(0.14)$ & $-0.1909(0.15)$ & $-0.2284(0.15)$ & $-0.2028(0.15)$ & $-0.2006(0.15)$ & $-0.198(0.15)$ \\
\hline Public insurance & & & & $-0.1953(0.13)$ & $-0.1688(0.13)$ & $-0.169(0.13)$ & -0.1685 (0.13) & $-0.1702(0.13)$ & $-0.1697(0.13)$ \\
\hline $\begin{array}{l}\text { Provider health locus } \\
\text { of control }^{2}\end{array}$ & & & & & $0.1245(0.08)$ & $\quad 0.1157(0.08)$ & $0.1168(0.08)$ & $0.1177(0.08)$ & $0.1177(0.08)$ \\
\hline $\begin{array}{l}\text { Chance health locus } \\
\text { of control }{ }^{2}\end{array}$ & & & & & $0.137(0.07)$ & $0.1567(0.07)$ & $0.1555(0.07)$ & $0.154(0.07)$ & $0.1532(0.07)$ \\
\hline $\begin{array}{l}\text { Internal health locus } \\
\text { of control }\end{array}$ & & & & & $-0.1019(0.06)$ & $-0.0877(0.06)$ & $-0.0959(0.06)$ & $-0.0969(0.06)$ & $-0.0975(0.06)$ \\
\hline $\begin{array}{l}\text { Nijmegen expectation } \\
\text { of GP scale }\end{array}$ & & & & & $0.1458(0.08)$ & $0.1497(0.08)$ & $0.1507(0.08)$ & $0.152(0.08)$ & $0.1516(0.08)$ \\
\hline Roman Catholic & & & & & & $0.7047(0.12)$ & $0.701(0.12)$ & $0.6976(0.12)$ & $0.7067(0.13)$ \\
\hline Environmentalist & & & & & & $0.3695(0.25)$ & $0.4014(0.25)$ & $0.4053(0.25)$ & $0.4085(0.25)$ \\
\hline Very strongly urban ${ }^{\text {b }}$ & & & & & & & $-0.3486(0.23)$ & $-0.3094(0.23)$ & $-0.2614(0.26)$ \\
\hline Strongly urban ${ }^{b}$ & & & & & & & $-0.1864(0.20)$ & $-0.1667(0.20)$ & $-0.1417(0.21)$ \\
\hline Intermediately urban ${ }^{b}$ & & & & & & & $-0.154(0.17)$ & $-0.1369(0.17)$ & $-0.1268(0.17)$ \\
\hline Little urban ${ }^{b}$ & & & & & & & $-0.1257(0.17)$ & $-0.1039(0.17)$ & $-0.0882(0.17)$ \\
\hline $\begin{array}{l}\text { GP practicing alternative } \\
\text { medicine }\end{array}$ & & & & & & & & $0.0330(0.08)$ & $0.0320(0.08)$ \\
\hline GP inclination to refer to & & & & & & & & $0.0378(0.10)$ & $0.0425(0.1)$ \\
\hline $\begin{array}{l}\text { alternative modicine } \\
\text { GP attitude towards } \\
\text { alternative medicine }\end{array}$ & & & & & & & & $-0.0872(0.11)$ & $-0.0906(0.10)$ \\
\hline Homeopathic GP & & & & & & & & $-0.0808(0.44)$ & $-0.0844(0.44)$ \\
\hline $\begin{array}{l}\text { Distance }(\mathrm{km}) \text { to nearest } \\
\text { paranoormal healer } \\
\text { andom }\end{array}$ & & & & & & & & & $0.0034(0.01)$ \\
\hline $\begin{array}{l}\text { Random } \\
\text { GP practice level }\end{array}$ & & & & & & & & & ) 0 \\
\hline $\begin{array}{l}\text { GP practioe level } \\
\text { Individual level }\end{array}$ & $1(0) \quad 0.1461(0.07)$ & $\begin{array}{l}0.1622(0.07) \\
1(0)\end{array}$ & ${ }_{1(0)}^{0.1559(0.07)}$ & $\begin{array}{l}0.1617(0.07) \\
1(0)\end{array}$ & $1(0)$ & $1(0)$ & $1(0)$ & $1(0)$ & $1(0)$ \\
\hline
\end{tabular}

Level 1 is individual, level 2 GP practice. Standard errors in parentheses. Al level-2 cases included. ${ }^{2}$ Higher scores indicate lesser orientation/expectation. ${ }^{b}$ Reference category 'not urban', 'R eference category 'no chroric condition'.

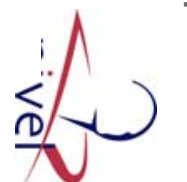


Table 4

Log-odds utilization of manual therapy in past 5 years

\begin{tabular}{|c|c|c|c|c|c|c|c|c|c|}
\hline & \multicolumn{9}{|c|}{ Results multilevel analyses } \\
\hline & 0 model & + health & $\begin{array}{l}\text { + demo- } \\
\text { graphics }\end{array}$ & $\begin{array}{l}+ \text { socio- } \\
\text { economic }\end{array}$ & + attitudes & $\begin{array}{l}\text { + religion/ } \\
\text { politics }\end{array}$ & + urbanicity & $\begin{array}{l}+ \text { GP charac- } \\
\text { teristics }\end{array}$ & + distance \\
\hline \multicolumn{10}{|l|}{ Fixed } \\
\hline Constant & $-3.572(0.09)$ & $-4.281(0.13)$ & $-4.721(0.18)$ & $-4.637(0.21)$ & $-4.615(0.21)$ & $-4.583(0.21)$ & $-4.96(0.27)$ & $-4.615(0.40)$ & $-4.449(0.44)$ \\
\hline $\begin{array}{l}\text { Self-evaluated health less } \\
\text { than good }\end{array}$ & & $0.0956(0.17)$ & $0.1365(0.17)$ & 7) $0.1947(0.17)$ & $0.2688(0.17)$ & 7) $0.2687(0.17)$ & $0.2576(0.17)$ & $0.2523(0.17)$ & $0.2552(0.17)$ \\
\hline Serious chr. cond. ${ }^{c}$ & & $-0.369(0.17)$ & $-0.2534(0.17)$ & 7) $-0.2177(0.17)$ & $-0.1735(0.17)$ & 7) $-0.171(0.17)$ & $-0.169(0.17)$ & $-0.1777(0.17)$ & $-0.1808(0.17)$ \\
\hline Intermed. chr. cond. ${ }^{c}$ & & $1.089(0.14)$ & $1.111(0.14)$ & $1.14(0.14)$ & $1.186(0.14)$ & $1.186(0.14)$ & $1.188(0.14)$ & $1.188(0.14)$ & $1.188(0.14)$ \\
\hline Minor chr. conditions ${ }^{c}$ & & $0.3483(0.13)$ & ) $\quad 0.3361(0.13)$ & 3) $0.3397(0.13)$ & ) $\quad 0.3324(0.13)$ & 3) $\quad 0.3338(0.13)$ & $0.3377(0.13)$ & $\quad 0.3387(0.13)$ & $0.3404(0.13)$ \\
\hline$\geq 2$ complaints & & $0.3236(0.14)$ & b) $0.3499(0.14)$ & f) $0.3576(0.14)$ & 6) $\quad 0.3386(0.14)$ & 4) $0.3367(0.14)$ & $0.3293(0.14)$ & $\quad 0.3293(0.15)$ & $0.3299(0.15)$ \\
\hline GHHQ & & $-0.0525(0.07)$ & $-0.0485(0.07)$ & $-0.0432(0.07)$ & $-0.0389(0.07)$ & 7) $-0.0377(0.07)$ & $-0.0376(0.07)$ & $-0.0409(0.07)$ & $-0.0427(0.07)$ \\
\hline BIOPRO & & $0.06(0.07)$ & $0.0373(0.07)$ & $0.0253(0.07)$ & $0.0224(0.07)$ & 7) $\quad 0.0218(0.07)$ & $0.0235(0.07)$ & $0.0253(0.07)$ & $0.0261(0.07)$ \\
\hline Female & & & $-0.1015(0.13)$ & $-0.0987(0.13)$ & $-0.0986(0.13)$ & 3) $-0.0979(0.13)$ & $-0.0964(0.13)$ & $-0.1027(0.13)$ & $-0.1019(0.13)$ \\
\hline Age $25-54$ & & & $0.7001(0.14)$ & f) $0.678(0.14)$ & $0.5996(0.14)$ & 4) $\quad 0.6005(0.14)$ & $0.6003(0.14)$ & $0.601(0.14)$ & $0.6044(0.14)$ \\
\hline Education high (rest) & & & & $0.2959(0.14)$ & b) $\quad 0.1962(0.15)$ & 5) $\quad 0.1953(0.15)$ & $0.1917(0.15)$ & $0.186(0.15)$ & $0.1784(0.15)$ \\
\hline Public insurance & & & & $-0.3034(0.14)$ & 6) $-0.2824(0.14)$ & 4) $-0.2834(0.14)$ & $-0.2873(0.14)$ & $-0.2743(0.14)$ & $-0.271(0.14)$ \\
\hline $\begin{array}{l}\text { Provider health locus } \\
\text { of control }^{2}\end{array}$ & & & & & $0.2396(0.09)$ & 9) $0.2404(0.09)$ & $0.2385(0.09)$ & $0.2334(0.09)$ & $0.2338(0.09)$ \\
\hline $\begin{array}{l}\text { Chance health locus } \\
\text { of control }{ }^{2}\end{array}$ & & & & & $0.0185(0.07)$ & 7) $\quad 0.0159(0.07)$ & $0.0181(0.07)$ & $0.0162(0.07)$ & $0.0177(0.07)$ \\
\hline $\begin{array}{l}\text { Internal heatth locus } \\
\text { of control }\end{array}$ & & & & & $-0.0427(0.06)$ & 6) $-0.0433(0.06)$ & $-0.0382(0.06)$ & $-0.0401(0.07)$ & $-0.0401(0.07)$ \\
\hline $\begin{array}{l}\text { Nijmegen expectation } \\
\text { of GP scale }\end{array}$ & & & & & $-0.0053(0.08)$ & 8) $-0.0072(0.08)$ & $-0.0076(0.08)$ & $-0.0080(0.08)$ & $-0.0087(0.08)$ \\
\hline Roman Cathobic & & & & & & $-0.0865(0.15)$ & $-0.0993(0.14)$ & $-0.0483(0.15)$ & $-0.0573(0.15)$ \\
\hline Enviror & & & & & & $0.0246(0.28)$ & $0.0512(0.28)$ & 0.0538 & $0.0513(0.28)$ \\
\hline Very strongly urban ${ }^{b}$ & & & & & & & $0.3799(0.30)$ & $0.3149(0.30)$ & $0.1453(0.35)$ \\
\hline Strongly urban ${ }^{b}$ & & & & & & & $0.2836(0.29)$ & $\quad 0.1743(0.29)$ & $0.0725(0.31)$ \\
\hline Intermediately urban & & & & & & & $0.5246(0.25)$ & $\quad \mathbf{0 5 0 3 7}(0.25)$ & $0.3995(0.27)$ \\
\hline Little urban & & & & & & & $0.6892(0.25)$ & $\quad 0.6159(0.25)$ & $0.5993(0.25)$ \\
\hline $\begin{array}{l}\text { GP practicing alternative } \\
\text { medicine }\end{array}$ & & & & & & & & $-0.2126(0.10)$ & $-0.2395(0.11)$ \\
\hline $\begin{array}{l}\text { GP inclination to refer to } \\
\text { alternative medicine }\end{array}$ & & & & & & & & $-0.0011(0.14)$ & $0.0007(0.14)$ \\
\hline $\begin{array}{l}\text { GP attitude towards alternatiw } \\
\text { medicine }\end{array}$ & & & & & & & & $0.0542(0.14)$ & $0.0830(0.14)$ \\
\hline Homeopathic GP & & & & & & & & $0.418(0.47)$ & $0.4064(0.48)$ \\
\hline $\begin{array}{l}\text { Distance }(\mathrm{km}) \text { to nearest } \\
\text { manual therapist } \\
\text { Random }\end{array}$ & & & & & & & & & $-0.0093(0.01)$ \\
\hline GP practice level & $0.3116(0.10)$ & $\quad 0.3399(0.11)$ & ) $\quad 0.3425(0.11)$ & ) $0.3097(0.10)$ & ) $\quad 0.2909(0.10)$ & 9) $\quad 0.2875(0.10)$ & $0.2247(0.09)$ & $0.1896(0.08)$ & $0.1963(0.08)$ \\
\hline Individual level & $1(0)$ & $1(0)$ & $1(0)$ & $1(0)$ & $1(0)$ & $1(0)$ & $1(0)$ & $1(0)$ & $1(0)$ \\
\hline
\end{tabular}

Standard errors in parentheses. Level 1 is individual, level 2 settlement of residence. Standard errors in parentheses. Sienificant effects only. All level-2 cases included ${ }^{2} \mathrm{Hi} h \mathrm{e}$

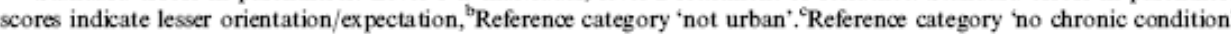

